\section{Identidades indígenas no ciberespaço}

Eliete da Silva Pereira. Ciborgues indigen@s.br: a presença nativa no ciberespaço. São Paulo, Annablume, 2012. 285 páginas.

\section{Denise Machado Cardoso}

A obra Ciborguesindigen@s.br: a presençanativa no ciberespaço apresenta uma análise sobre o uso das tecnologias comunicativas no contexto contemporâneo, enfatizando questôes de identidade de indígenas brasileiros. Suas quatro partes discutem, respectivamente: as mídias nativas e a comunicação indígena no Brasil; a presença indígena no ciberespaço; as interpretaçōes indígenas sobre a internet; e, por fim, os debates ensejados pelas três seçôes anteriores.

Ainda na introdução do livro, a autora aborda questôes sobre interações comunicativas e as especificidades da presença indígena no ciberespaço. Nesse sentido, ela propóe, com base em sua experiência investigativa sobre o tema, explorado na sua dissertação de mestrado, analisar a dinamicidade cultural inerente às novas estratégias para tentar solucionar problemas históricos.

A problemática central se refere ao modo como indígenas brasileiros se apropriam das tecnologias comunicativas digitais e como eles interagem, proporcionando reelaborações de discursos sobre si. Contudo, a autora ressalta que essa apropriação ainda é um desafio, apesar da nova condição nativa contemporânea, em que indígenas participam como usuários e produtores de conteúdo, e das ações governamentais e não governamentais com vistas à inclusão digital. Vários são os exemplos desse esforço pela implementação de políticas de inclusão digital, mas a questão é mais complexa do que se pode supor. Independentemente das ações voltadas para essa inclusão, os grupos indígenas estão ocupando o ciberespaço com estratégias comunicativas interessantes que se refletem em novas maneiras de pressionar por açóes governamentais e outras de organismos não governamentais. Desse modo, a internet contribui como ambiente de interaçôes comunicativas que reforçam a cidadania dos indígenas em suas várias demandas.
Em termos de metodologia, a discussão sobre o fazer etnográfico enfatiza o contexto da investigação, o que levou a autora a utilizar também a etnografia do virtual, realizando a pesquisa sobre a interação comunicativa de grupos indígenas em blogs, sites e redes sociais, em parte, diretamente nesses espaços. Há um debate interessante sobre a possibilidade de a investigação antropológica ser feita no campo da virtualidade, problematizando as obras que lhe serviram de inspiração e conduziram seu trabalho.

Torna-se possível, assim, a reflexão acerca de um tema que a autora considera provocativo, que é o de as representações que ainda se fazem sobre os indígenas, notadamente aquelas relacionadas aos estudos antropológicos, nem sempre condizerem com as imagens que os indígenas constroem sobre si. Essa situação se justifica pela permanência no imaginário de que esses grupos são selvagens e de que precisam ser tutelados.

Discutir o modo de fazer pesquisa antropológica com indígenas remete à tradição do trabalho de campo e à necessidade de pesquisadores se deslocarem para realizá-lo. Consequentemente, a visão que se tinha do trabalho de campo com grupos indígenas precisa ser revista de acordo com a construção de sua autopercepção e com o uso que fazem da internet para se articularem e buscarem o atendimento de suas demandas, alterando assim sua relação com o Estado e com o restante da sociedade. Diante desse problema metodológico, a autora detalha o universo pesquisado. A fim de caracterizar a sociabilidade tecnossocial dos grupos estudados, ela fez o mapeamento de cinquenta sites de acordo com a autoidentificação indígena de etnias situadas no Brasil. Outros critérios de classificação foram os níveis de interatividade e a arquitetura de informação e conteúdo. Ao expor as estratégias empregadas, ela explica a relevância dos sites como fontes eletrônicas para análises de narrativas hipertextuais. Para refinar as interpretações dos significados da internet sob a perspectiva dos próprios indígenas, foram realizadas entrevistas com alguns deles.

Após essa introdução, os capítulos da primeira parte enfatizam a discussão sobre o fenômeno tecnológico e comunicativo presente na rede mundial 
de computadores. Nas partes seguintes apresentam-se os dados relativos à pesquisa empírica, isto é, à investigação teórica e de campo, e suas conclusões.

O capítulo "Mídias nativas" debate os significados da comunicação indígena, embasando-se em obras sobre o modo como os grupos indígenas se apropriam das tecnologias comunicacionais presentes desde o processo de colonização do continente americano. Nesses termos, a autora indica que a difusão de mídias foi instrumentalizada com vistas à consagração da hegemonia cultural dos colonizadores sobre as culturas indígenas. Contudo, revela que essa mesma hegemonia também foi apropriada em diversos momentos como instrumento de "multiplicação de visōes de mundo". A mídia como elemento da mediação cultural proposta por Martín-Barbero (2001) e as reflexões críticas de Hall (2003) acerca do modelo linear de comunicação emissor/receptor são considerações exemplares sobre as apropriações por grupos não hegemônicos. O protagonismo de grupos até então subalternos foi alcançado por essa apropriação da mídia, entre outros fatores. Assim, a mídia nativa se refere às potencialidades de experimentaçōes multimidiáticas $\mathrm{em} / \mathrm{da}$ rede por grupos indígenas e de periferia.

A autora então argumenta que a expressividade corporal é a instância primeira da comunicação, remetendo-se às pesquisas de Viveiros de Castro (2002). A semiótica do corpo indígena (mas não exclusivamente desses grupos humanos) implica sua articulação recíproca com o ambiente. O corpo não separado de sua essência (alma ou espírito) em muito difere da concepção de grupos não indígenas, e isso marca a maneira como veem a si próprios, o mundo e a relação com outros humanos e não humanos.

No que se refere à mídia nativa radiofônica, há indicações sobre os usos em termos de rádio comunitária e as implicações legais e instrumentais relacionadas à causa indígena. Notadamente, sua relevância nas aldeias tem demandas específicas tanto para serviços de saúde e abastecimento de materiais, por exemplo, como para reforçar a luta pela causa indígena. Em relação à mídia nativa audiovisual, a autora retoma a ideia apresentada nas reflexões anteriores por considerar que, como a oralidade, a visualidade também é relevante. $\mathrm{O}$ vídeo é, segundo ela, aquilo que os indígenas mais absorvem e incorporam como importante ferramenta de mediação cultural: por meio dele, deixam de ser espectadores para se tornarem produtores. Experiências como o projeto pioneiro Vídeo nas Aldeias, da década de 1980, possibilitaram o que a autora chama, com base na denominação de Vincent Carelli, de "consciência aguda do processo de transformação", ou seja, autoconsciência coletiva da diversidade e mudanças nas culturas indígenas.

Em sua análise da mídia nativa escrita, ela ressalta que a passagem da oralidade para escrita é um processo complexo diante das características expostas anteriormente. Essa transição ganhou destaque a ponto de inúmeros trabalhos terem sido realizados com o intuito de explicar questões de alfabetização e escrita, notadamente a partir das propostas de educação escolar bilíngue. O debate acerca dessa questão não se encerra na educação escolar e se amplia para as reflexões sobre a literatura indígena e, atualmente, sobre o papel da escrita digital.

O capítulo que inicia a segunda parte do livro discute brevemente as novas práticas comunicativas, com a internet e a presença indígena no ciberespaço. Também discorre sobre aspectos históricos da cultura digital, desde a Arpanet, na década de 1960, até a disseminação do uso da rede mundial de computadores no fim do século XX. A autora faz referência a obras de cientistas renomados, como Castells (2003), Eco (1970), Santaella (2003), entre outros. Os capítulos seguintes avançam para a questão da nova sociabilidade tecnossocial proporcionada pelo ciberespaço. $\mathrm{O}$ espaço de comunicação se torna fecundo na medida em que se cria um novo ecossistema tecnossocial, ou seja, na medida em que a interatividade da cibercultura proporciona novas formas de sociabilidades. No caso indígena, a internet possibilita a integração de múltiplos pontos de vista.

O quarto capítulo apresenta um estudo de caso do movimento zapatista. Esse estudo subsidia questões de capítulos posteriores, notadamente aquelas que analisam as açōes e impressões dos indígenas sobre os usos da internet. No capítulo que trata do percurso do mapeamento dos sites indígenas, há uma breve caracterização das modalidades de interatividade e arquitetura de informação - portais, 
blogs, redes sociais digitais e sites - a partir da qual a autora passa a discutir a presença indígena no ciberespaço. Esta ocorre especificamente nos diversos blogs e sites de diferentes etnias e de organizaçōes nacionais, regionais e locais. A autora então verifica a potencialidade do ciberespaço para a promoção do protagonismo indígena no Brasil, como ocorreu em outras realidades. Com base no movimento zapatista (apesar de não ser um movimento genuinamente indígena) tece consideraçôes sobre o ambiente informacional - o ciberespaço - como espaço de ativismo político.

A contribuição desses capítulos para a compreensão do ativismo político indígena no ciberespaço é significativa e inovadora, pois por meio deles se podem perceber as demandas e ações indígenas em termos tanto quantitativos quanto qualitativos. Em sua descrição, há uma série de possibilidades a ponderar, como as açôes políticas em rede, os movimentos indígenas de mulheres, de professores, de jovens etc. As temáticas são diversas e revelam a complexidade e a amplitude desses sujeitos políticos no ciberespaço. $\mathrm{O}$ modo como rearticulam o discurso étnico a favor de suas especificidades estimula novos olhares e reflexões.

A terceira parte do livro revela as interpretações indígenas sobre a internet, somando as entrevistas e os relatos às discussões sobre o diálogo na produção antropológica e reforçando a percepção de que houve avanços consideráveis. Exemplos como o projeto Índios Online e o Arco Digital dão conta de que a internet é um recurso essencial para o movimento, pois possibilita maior visibilidade, contato com pessoas e apoiadores da questão indígena, reforço da presença e da expressão de um pertencimento étnico indígena. No que se refere à produção antropológica, enfatizam a concepção de que há um estilo próprio de fazer ciência a partir da etnografia. Desse modo, os questionamentos e ponderações sobre a pesquisa de campo são retomados com referências às obras do antropólogo Crapanzano (1988) e do filósofo Gadamer (1986). Em seguida, a autora discute a proteção dos conhecimentos tradicionais, o fortalecimento cultural, a globalização indígena e a divulgação da literatura indígena.

$\mathrm{Na}$ quarta parte, os capítulos dez e onze encerram o debate com o que chamam de "ciborgue indígena” - uma metáfora de mistura (hibridismo) das conexões entre as mídias e os seres humanos sustentando sua critica à visão dualista entre seres humanos e técnicas marcantes nos ideais platônicos. Assim, a autora propõe a superação da perspectiva de análise sustentada na dicotomia entre humanos e tecnologia e indica, ao mesmo tempo, que essa visão se aplique também na relação entre humanos e natureza. Desse modo, indígenas deixariam de ser associados apenas ao polo da natureza, potencializando a esses povos uma nova representação e novos papéis diante das dinâmicas socioculturais no ciberespaço.

Por fim, o livro retoma as reflexões desenvolvidas por Martin Heidegger acerca da essência da técnica, pois para esse pensador o Ser, antes de substantivo, é verbo. O ser humano provoca e é provocado pela técnica, e ela não pode ser reduzida ao instrumento. Consequentemente, o Ser significa o encontro entre terra, deuses, coisas e mortais. No ciberespaço, ou seja, na comunicação mediada por computadores, a informação é um modo de ser.

A crítica à oposição entre natureza e cultura é reforçada por Donna Haraway - ao associar essa visão ao seu caráter ideológico - e exemplifica com a denúncia de que tal dicotomia alija determinados grupos sociais do âmbito da cultura, tal como ocorre com as mulheres e se aplica aos grupos indígenas. Assim, pensar de modo dicotômico pode levar a raciocínios falhos na medida em que exclui a possibilidade de analisar o ciberespaço como um meio híbrido de inteligências e saberes. Em síntese, o livro emprega a ideia de "ciborgue indígena" na tentativa de explicar a resignificação das experiências indígenas e suas identidades no ciberespaço.

\section{BIBLIOGRAFIA}

CARELLI, Vincent. (1989), Video nas aldeias. São Paulo. Disponível em www.youtube. com/watch?v=tdI7uXpvy, consultado em $12 / 4 / 2014$

CASTELLS, Manuel. (2003), A galáxia da internet: reflexões sobre a internet, os negócios e a sociedade. Rio de Janeiro, Jorge Zahar. 
CASTRO, Eduardo Viveiros de. (2002), A inconstância da alma selvagem e outros ensaios de antropologia. São Paulo, Cosac Naify.

CRAPANZANO, Vincent. (1988), "Diálogo". Anuário antropológico, n. 88. Brasília, Editora $\mathrm{UnB} /$ Tempo Brasileiro.

ECO, Umberto. (1970), Apocalípticos e integrados. São Paulo, Perspectiva, 1970.

GADAMER, Hans-Georg. (1986), The relevance of the beautiful and other essays. Cambridge, Cambridge University Press.

HALL, Stuart. (2003), Da diáspora: identidades e mediações culturais. Belo Horizonte, Editora UFMG.

HARAWAY, Donna. (2000), "Manifesto Ciborgue: ciência, tecnologia e feminismo-socialista no final do século XX", in H. Kunzru e T. T. Silva (orgs.), Antropologia do ciborgue: as vertigens do pós-humano, Belo Horizonte, Autêntica.

HEIDEGGER, Martin. (1994), "La pregunta por la técnica", in , Conferencias y artículos, Barcelona, Ediciones del Serbal. Disponível em www.monografias.com/trabajos-pdf/pregunta-tecnica/pregunta-tecnica.pdf, consultado em 23/2/2014.

MARTÍN-BARBERO, Jesús. (2001), Dos meios às mediações: comunicação, cultura e hegemonia. Rio de Janeiro, Editora UFRJ, 2001.

SANTAELLA, Lucia (2003), Culturas e artes do pós-humano: da cultura das mídias à cibercultura. São Paulo, Paulus.

\section{DENISE MACHADO CARDOSO é antropóloga, doutora em desenvolvimento socioambiental e docente de ciências sociais da Universidade Federal do Pará. E-mail: denise@ufba.br.}

\section{A propósito de emancipação em Christophe Dejours}

Christophe Dejours. Trabalho vivo: trabalho $e$ emancipação. Brasília, Paralelo 15, 2012, 2 vols. 436 páginas.

\section{Sadi Dal Rosso}

Christophe Dejours é amplamente conhecido por suas críticas às teses neoliberais que defendem princípios e práticas de organização do trabalho, cujas consequências para os trabalhadores são conhecidas na sociologia, antropologia, psicologia, gestão do trabalho e economia. É significativa sua contribuição para o estudo das relaçôes entre subjetividade e trabalho e grande estimulador da psicodinâmica do trabalho. Em 2012, a editora Paralelo 15, de Brasília, publicou Trabalho vivo: trabalho e emancipação, livro organizado em dois volumes: o primeiro, sobre sexualidade e trabalho; o segundo, a respeito de trabalho e emancipação.

As 436 páginas da obra atestam a grandiosidade do empreendimento intelectual do autor, que visa não só relacionar sexualidade e trabalho, mas também desenvolver uma ousada proposta de emancipação. Do ponto de vista metodológico, seus fundamentos ancoram-se em debates teóricos sobre o sentido do trabalho para a realização ou desgraça humanas, disponíveis na ampla literatura das ciências sociais e da psicanálise e em conhecimentos práticos decorrentes da longa experiência adquirida em práticas clínicas.

O livro investiga que relações existem e podem ser desenvolvidas entre a centralidade da sexualidade e a centralidade do trabalho. A centralidade da sexualidade para o ser humano é desenvolvida com base em conceitos e teses de Freud e de outros autores. Já a centralidade do trabalho, como é tratada no livro, resulta de uma elaboração própria do autor, que combina, de maneira muito particular, as relações entre afeto e trabalho. Os pesquisadores das ciências sociais sabem que essa questão começou a colocar-se para os conhecimentos do trabalho a partir do advento da modernidade, quando questōes magnas - tais como construir teoricamente uma explicação para os fundamentos do valor no trabalho - tornaram-se necessárias e o trabalho 